\title{
家屋の浸水試験方法とその実施例 \\ INUNDATION TEST METHOD FOR FLOODED HOUSES WITH APPLICATION
}

\author{
桑村 仁*, 小山 毅**, 奥 野 寛 樹***, 佐 藤 恵 治*** \\ Hitoshi KUWAMURA, Tsuyoshi KOYAMA, Hiroki OKUNO \\ and Yoshiharu SATO
}

\begin{abstract}
A testing method for quantifying inundation resistance of flooded houses is developed and is applied to a housing wall furnished with a window. The testing apparatus is composed of a main frame for fixing the tested wall, a reservoir and piping for supplying the outdoor floodwater, and a collector for gathering the inflow of water. The water depths of outside inundation space and inside collector are continuously measured by level gauges. The inundation flows from outside to inside are through an opening for under-floor ventilation, a joint discontinuity at the bottom of wall, and gaps in and around the sash frame of the window. The dimensions and heights of these floodwater inlets are estimated from the test results by employing Torricelli's theorem. Such information will enable engineers to calculate the rate of indoor inundation, which is substantially important for evacuation of residents and valuables.
\end{abstract}

Keywords : Inundation test, Hydro-hazard, Flood, Tsunami, Housing wall, Window sash 浸水試験，水害，洪水，津波，家屋壁体，空サッシ

\section{1. 序}

2011年東北地方太平洋沖地震による大津波や近年頻発する大雨 洪水によっておびただしい数の建築物が浸水被害を受けている。政 府の水害統計によると, 水害による全国の建築物の被害総額は, 年 によってかなり変動するが, 毎年数千億円に達している。家屋の被 害率 (家屋資産価值の喪失率) は浸水深とともに増大し，床上浸水 $1 \mathrm{~m}$ 以上で被害率が約 $40 \%$ 以上に達するとされている11。古くから水 害による社会的損失の程度は理科年表等に見られるように家屋浸水 何万棟というような数字で表現され, 建築物の被害が水害の指標に 使われている。水害という自然災害に対して建築物単体は今のとこ ろ無策であり, むしろ手の打ちようが無いという諦観が固定化して いるが，これを放置しておくと，建築技術者は水害のたびに，たと え非難を受けないにしても, 屈辱を味わい続けることになる。

いままで都市や市街地の洪水対策は海岸や河川での土木的治水に 頼ってきた。しかし, それには限界があり, 陸上汇濫を完全に防ぐ ことが不可能であることを近年の水害はまざまざと見せつけている し，治水行政自らもそれを認めるようになってきた22,3),4),5)。このこ とは建築学が建築物の浸水対策を自ら講じなければならない状沉が
到来したことを告げており，建築技術者は建築物の水害対策に覚醒 しなければならない。

水害対策を市民に訴える動きは近年盛んになり，水害八ザードマ ップや水害対策マニュアル6)が公表されているが，建築技術者の意 識は震害に偏り過ぎており，水害に対する意識はまだ低いと言わざ るを得ない。かつて, 治水対策の一環として建築物の耐水化が土木 分野で検討されたことがあるが7)，この動きに建築行政が呼応しな かったことも反省する必要があろう。

建築構造学における防水性・耐水性は様々な意味合いで捉えられ るが，大別すると，材料自体の水密性（water proof）, 雨水に対す る構法上の防水性（rain proof），及び洪水に対する耐浸水性（flood proof）の三つに分けられる。前二者は材料・施工・構法の分野に属 し，たくさんの既往研究があるが，本論が対象とする三番目の研究 はこれらとは技術的基盤が異なるものとして位置づけられる。

建築物の浸水に関する研究は, 避難や復旧に関する建築計画的な アプローチが近年盛んになってきたが，建築構造的な研究は非常に 乏しい。2011年の東北地方沿岸の大津波災害を契機に，鋼製ドアの 静水圧に対寸る耐力と漏水に関寸る研究8) や, RCビルの津波浸水に
* 東京大学大学院工学系研究科建築学専攻 教授·Ph.D

** 東京大学大学院工学系研究科建築学専攻 助教 $\cdot$ Ph.D.

****東京大学大学院工学系研究科建築学専攻 大学院生. 学士 (工学)
Prof., Dept. of Architecture, School of Engineering, The University of Tokyo, Ph.D Assist. Prof., Dept. of Architecture, School of Engineering, The University of Tokyo, Ph.D. Grad. Stud., Dept. of Architecture, School of Engineering, The University of Tokyo, B. Eng. 
関する流体力学的な研究9)が見られるのみで, 家屋の外周を対象と した浸水の研究はまだ緒についていないようである。海外では建築 構造学がCivil Engineeringの中に入っている関係で, 建築構造部門 と土木水理部門の連携が我が国よりも有効に働いており, 洪水対策 の技術指針が刊行されているとはいえ, 米国基準10)においても家屋 の浸水対策を扱ってはいない。

本研究は, 建具を含んだ家屋外周壁の浸水性能を調べる試験方法 を考案し，その実施例を紹介したものである。現時点では，建築物 の換気に関する法規制があるため, 屋内を屋外から密閉することが できず, したがって, 屋外に水が満ちたとき屋内の浸水を防ぐこと は不可能である。本研究は, 現状の設計施工によって建てられた住 宅の内部にどの程度の速さで水が流入するかを定量化することに主 眼を置いている。浸水を防止するアイデアは今後, さまざまな形で 提案されるであろうが，それについては言及せず，その基本となる 屋内浸水の数理的な捉え方について検討した。

\section{2. 浸水試験装置及び試験方法}

\section{1 浸水試験装置}

浸水試験装置は Fig.1 に示すように, 本体 (main frame), 貯水 槽 (reservoir), 集水槽 (collector) から成り, ある程度汎用的に 建物外周壁からの浸水を再現できるように設計されている。本体は 鉄骨製，貯水槽と集水槽はポリエチレン製容器である。本体は，試 験体（建具を含む家屋外壁）を固定でき，その屋外側の浸水空間（以 下，屋外浸水空間 outer inundation space）を深さ $3 \mathrm{~m}$ まで浸水さ せることができるようになっている。貯水槽は本体に注水する水を 貯めておくためのもので, その容量は $1.5 \mathrm{~m}^{3}$ であるが, 不足すると きは水道水を補給しながら試験を行う。集水槽は屋内側に流入寸る 水を集めるためのもので，容量は $0.13 \mathrm{~m}^{3}$ （有効内寸 $\mathrm{L} 910 \times \mathrm{W} 760$ $\times \mathrm{H} 200 \mathrm{~mm}$ ) である。注水には水中ポンプを使い, 貯水槽から屋外 浸水空間に上部からホース（内径 $25 \mathrm{~mm}$ ）を入れ, 吐出口を底部に 固定して注水する。ポンプの吐出量は $0.11 \mathrm{~m}^{3} / \mathrm{min}$ である。これに よる屋外浸水空間の水位上昇速度は約 $0.16 \mathrm{~m} / \mathrm{min}$ で, これは河川決 壊付近の比較的速い水位上昇速度 11$)$ の下限あたりの数值と想定さ れる。試験終了後は, 屋外浸水空間に溜まった水をポンプで貯水槽 に戻し，水を再使用する。

Fig. 2 に, 本体の鉛直断面と水平断面を, 試験体を設置した状態 で描いてある。本体の構造はH形鋼の柱と梁で組んだラーメンフレ 一ム 2 組を骨格とし, 底面の床板 1 枚と側面の壁板 2 枚をフレーム に連続隅肉溶接している。試験体を設置する際, その屋外側を作業 用に開けておく必要があるので, 屋外側は取り外し可能な鋼板パネ ル (以下, 着脱パネル) とし, 試験体を設置した後, 吊り入れてボ ルト止めする方法を採用した。このとき, 止水のために, 着脱パネ ルと接触する鉄骨フレーム面に帯状の低反発 EPDM ゴムスポンジ （断面 $20 \times 20 \mathrm{~mm}$ ）を貼り付けておき, 水圧によって防水性を確保 することとした。試験体の屋内側及び本体上部は開放されている。

試験体を下から支える基礎梁は，戸建住宅の場合，通常，鉄筋コ ンクリートの布基礎となるが，基礎を切り欠く形式の換気口が無い 限り, この部分は水密であると考えて試験対象とはせず, 試験体の 設置を簡単にするため, 角形鋼管（ $\square-200 \times 150 \times 9 \mathrm{~mm} ）$ を 2 段 積みとした基礎とし，その合せ目を連続フレア溶接して防水性を確

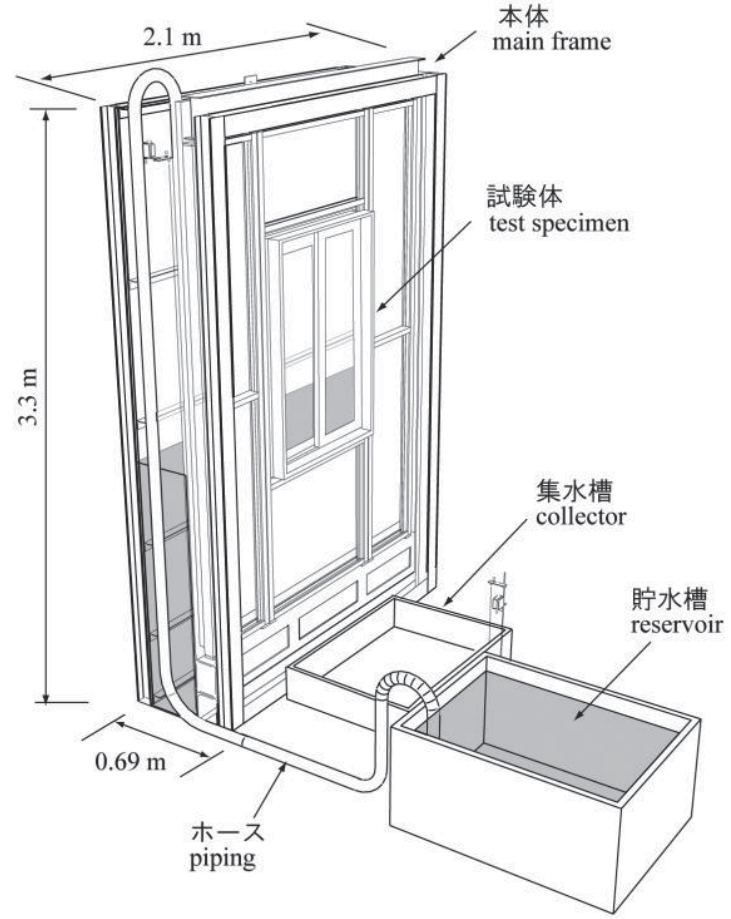

Fig.1 Perspective outline of inundation test

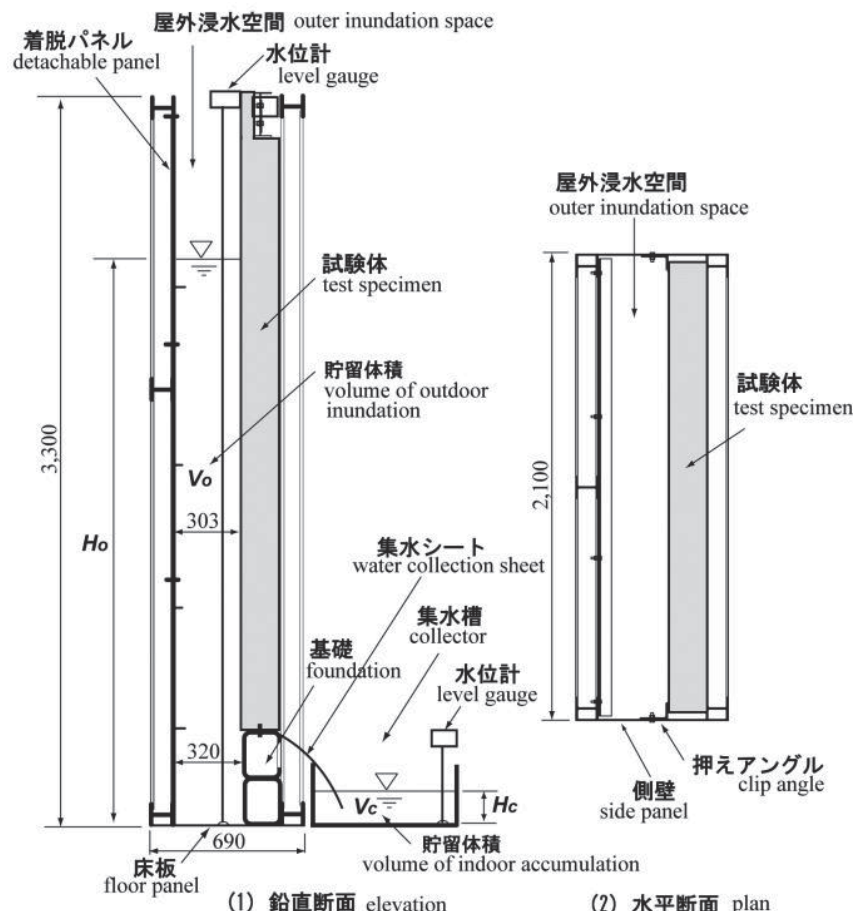

Fig.2 Vertical and horizontal sections of testing apparatus

保した。上の段の角形鋼管には屋内側に開口を設け，試験体の下部 をアンカーボルト締めできるようにした。試験体の両サイドの縦方 向設置ラインからの漏水を防止するため，装置の側壁に設けた押え アングルと試験体との間をシリコンコーキングした。

以上により, 試験体の屋外側すなわち屋外浸水空間は, 床板, 側 壁，着脱パネル，基䃈，試験体で囲まれ，そこに注入した水は試験 
体の空隙のみから屋内側に浸入することとなる。屋内に流入した水 は, 基礎梁上部に張った集水シートの上に流れ出し, すべて集水槽 に集められるようにしてある。

\section{2 計測センサーと測定量}

試験装置に設置した計測センサーは容量式水位計 2 台である。1 台の容量線 (level gauge) は屋外浸水空間に鉛直に張り, 装置の床 板からの浸水深を計測する。その容量線の径は $8 \mathrm{~mm}$, 容量（最大 計測深）は $2.7 \mathrm{~m}$ とした。もう 1 台の水位計の容量線は集水槽に鉛 直に張り, 屋内側に漏孔出した水の量を測る。その容量線の径は $4 \mathrm{~mm}$, 容量は $500 \mathrm{~mm}$ である。水位は時々刻々変化するが, その時 間的な変化率は急激ではないので, サンプリングデータを $0.2 \mathrm{~Hz}$ 程 度にならして分析を行うこととする。

水位計で計測された水深から貯留体積を求める式は,

$$
\begin{array}{r}
\text { 屋外浸水空間について: } V_{o}=H_{o} W_{o} L_{o} \\
\text { 集水槽について: } V_{c}=H_{c} W_{c} L_{c}
\end{array}
$$

である。ここで, $V_{o}=$ 屋外浸水空間に溜まった水の体積, $V_{c}=$ 集水 槽に溜まった水の体積, $H_{o}=$ 屋外浸水空間の水深, $H_{c}=$ 集水槽の水 深, $W_{o}=$ 屋外浸水空間の幅 (基礎天端の下で $320 \mathrm{~mm}$, 上で $303 \mathrm{~mm}$ ), $L_{o}=$ 屋外浸水空間の長さ $(2,100 \mathrm{~mm}), W_{c}=$ 集水槽の幅 $(760 \mathrm{~mm})$, $L_{c}=$ 集水槽の長さ $(910 \mathrm{~mm})$ である。

\section{3. 浸水試験の実施例}

\section{1 試験体}

今回用いた試験体は，Fig.3 に示すように，鉄骨系プレハブ住宅 の空を有する外壁の 1 ユニット $($ 幅 $2 \mathrm{~m} \times$ 高さ $3 \mathrm{~m})$ である。これは, 八ウスメーカーから供給されたもので, 特別な耐水性能をもつもの ではなく，一般に使用されているものである。

外壁を支える鉄骨下地は間柱に相当する縦材と胴縁に相当する横 材が軽量形鋼, 上部横架材が 2 階の床梁を兼ねる $\mathrm{H}$ 形鋼である。縦 材の脚部にはベースプレートが溶接されており, 試験装置の鋼製基 礎（2 段の角形鋼管）の上部にボルトでアンカーされる。このベー スプレートの厚さ分 $16 \mathrm{~mm}$ が, いわゆるネコ土台あるいはパッキン と呼ばれるものに相当し, それによってスリット状の床下換気口 (形 態としては基礎上換気口）が設けられる格好になる。上部横架材は 試験装置の本体フレームを構成する梁にボルト接合される。

外壁は窯業系サイディング（JIS A 5422，厚さ $33 \mathrm{~mm}$ ）で，縦方 向のみに目地がある。その縦目地は水密シート, シールジョイント で防水処理されている。断熱材や内壁材，床材は浸水性能と直接関 係しないので取り外し, 浸入した水が停滞することなくすべて集水 槽に流れ落ちるようにした。

空はアルミサッシの引違いである。サッシの寸法は幅 $959 \mathrm{~mm}$, 高さ $1,340 \mathrm{~mm}$ で, JIS A 4706 による等級は, 耐風圧性が S-2, 気 密性が $\mathrm{A}-4$, 水密性が $\mathrm{W}-4$, 遮音性が $\mathrm{T}-1$, 断熱性が $\mathrm{H}-4$ である。

\section{2 予備テスト}

浸水試験に先立ち, 試験装置からの漏水が無いことを確認するた めに満水テストを行った。次項に述べる試験体の想定浸水口をすべ て塞いで屋外浸水空間の水位を徐々に上げていったところ，水位が $2.87 \mathrm{~m}$ （テープメジャーの読取り值）に達したところで試験体の外 壁パネルの屋内側にき裂が走った。これは静水圧によって窯業系サ イディングパネルに曲げが加わり, 引張応力が生じる屋内側に曲げ

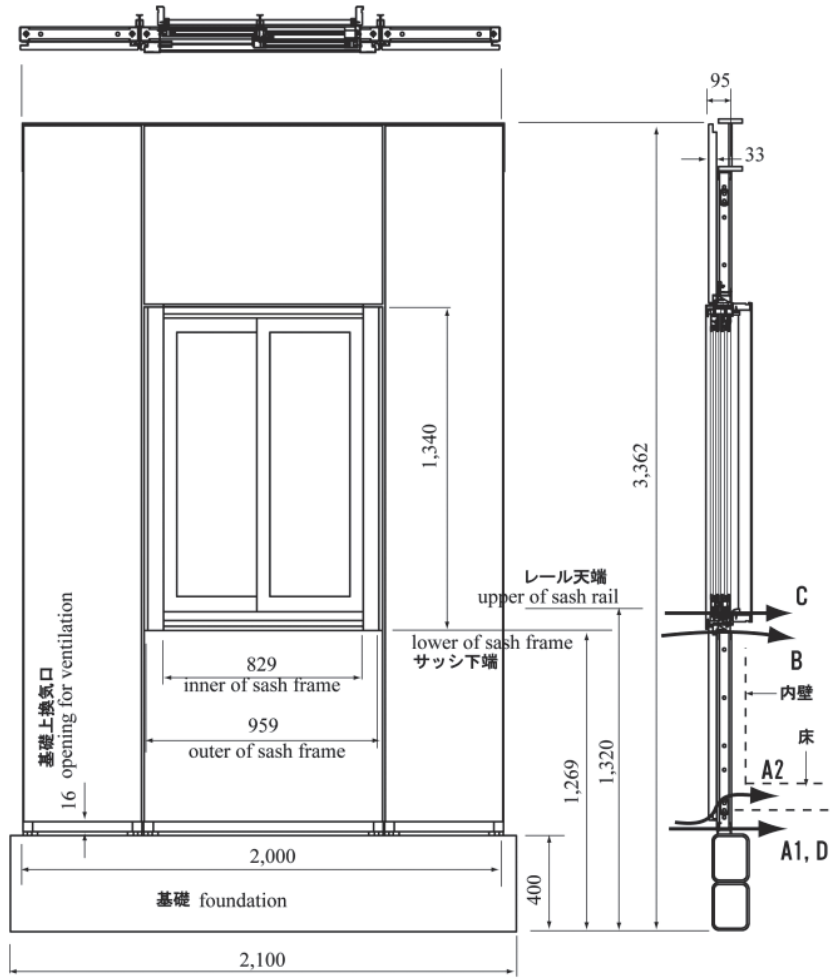

Fig.3 Test specimen (unit of external wall)

き裂が生じたものである。ただし，き裂は屋外面には貫通せず，き 裂部分からの漏水は生じなかった。この結果に基づき，今回の浸水 試験での屋外浸水深は安全を見て $2 \mathrm{~m}$ までとした。

以上の予備テストにおいて, 試験装置の水密性が確保されている こと, 及び外壁サイディングとその目地などの水密性も保持されて いることが確認できた。なお，外壁サイディングのき裂部分は屋内 側からガラス繊維とエポキシ樹脂で補修して, 本試験を実施するこ ととした。

\section{3 試験体の浸水口}

建物の外周には複数の浸水口があり，それを区分する基準は現時 点では整っていないので, 本研究では浸水口を想定して実験を行っ た。将来的には, 浸水口は換気計算を行う際の換気口と同様の分類 が可能と思われる。個々の浸水口の高さ方向の位置と面積が分かれ ば，浸水流量を計算することができるはずで，本研究はそこに焦点 を当てている。

想定される水の浸入経路として, Fig.3の縦断面図に示す A1, A2, $\mathrm{B} ， \mathrm{C}$ の 4 か所の開口あるいは隙間が考えられる。浸水口 $\mathrm{A} 1$ は基礎 梁と壁体の間に計画的に設けられた換気用の開口（以下，基礎上換 気口）で，外壁の幅全体にわたる連続した開口であり，その高さ方 向の開口幅は $16 \mathrm{~mm}$ である。この基礎上換気口から流入した水は直 ちに床下を浸水させる。浸水口 A2 は A 1 の寸ぐ手前上部にある壁体 と下地鉄骨のジョイントの隙間（以下，外壁下端ジョイント隙間） である。ここを通った水は床下または内壁を浸透して床材を污損す る。なお，壁体内換気用の通気口は $\mathrm{A} 1$ とつながっている。浸水口 B は空サッシ枠と壁材の間に存在する不可避の隙間（以下，サッシ枠 外隙間）である。浸水口 C は空サッシ枠内にある隙間（以下，サッ シ枠内隙間）で，サッシ下枠に設けられた結露排水口，引違い戸と 
サッシ枠の隙間, 及び引違い戸の召合せの隙間から成る。なお, こ のサッシ枠内隙間は引違い戸を施錠した状態とする。

以上の浸水口に加え，位置と寸法を指定した開口（高さ $16 \mathrm{~mm} \times$

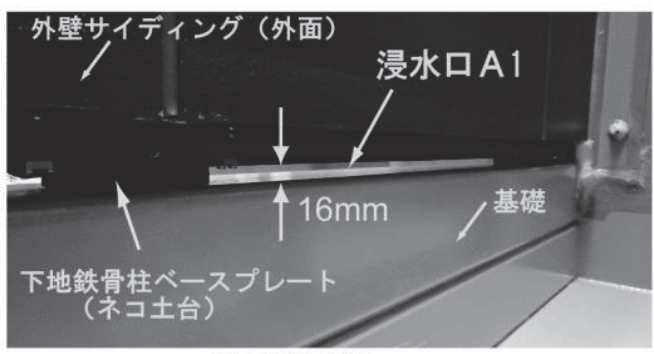

(1) 浸水口A1

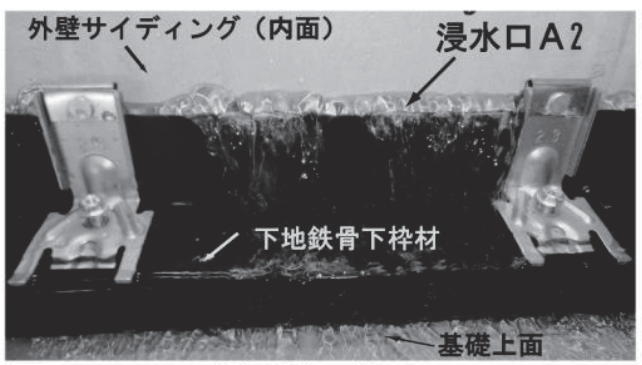

(2) 浸水口A2

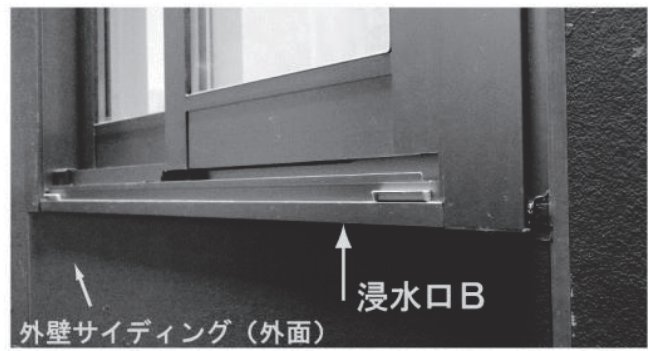

(3) 浸水口B

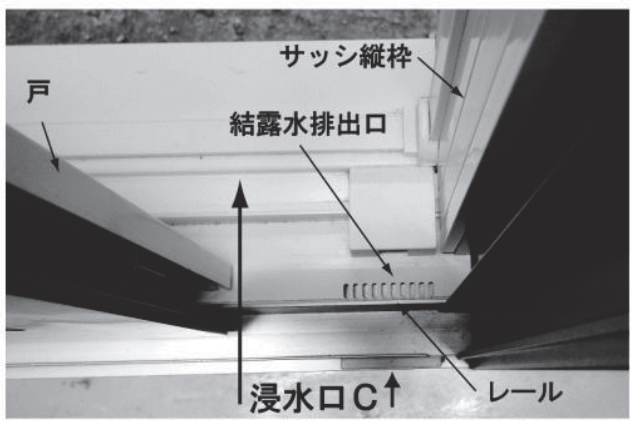

(4) 浸水口C

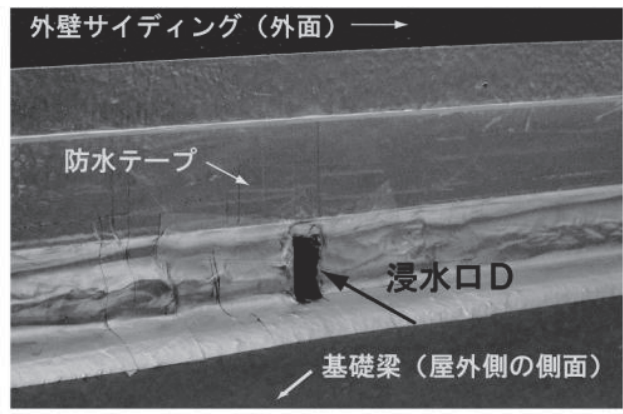

(5) 浸水口D

Fig.4 Pictures of floodwater inlets
横幅 $10 \mathrm{~mm}$ ）を基礎上に意図的に開け，これを浸水口 D とする。浸 水口 D は, 浸水試験から得られる浸水口の面積やレベルなどが正し く検出されていることを確認するためのものである。

以上により，浸水試験の対象となる浸水口をまとめると次のよう になる。Fig.4にそれぞれの写真を掲載しておいた。

浸水口 $\mathrm{A} 1$ : 基礎上換気口（高さ方向の幅 $16 \mathrm{~mm}$ ）

浸水口 A2 : 外壁下端ジョイント隙間

浸水口 B : 空サッシ枠外隙間（サッシ枠と壁材の隙間）

浸水口 C : 空サッシ枠内隙間（結露排水口，戸車付き下框とレー ル間，戸当たり，召合せ）

浸水口 D : 基礎上に意図的に設けた指定開口（寸法：16×10mm） 3.4 浸水試験の手順

以上の浸水口を想定して, 次のようなテスト $1 \sim 5$ の浸水試験を 段階的に行うこととした。それぞれ 3 回ずつ行った。

テスト 1 : 基礎上換気口（浸水口 A1）からの浸水状況を調べる試 験で，空サッシ下枠より下のレベルまで屋外浸水空間に注水を 試みる。状況によっては, 浸水口 A2 からも浸水する。

テスト 2 : 浸水口 $\mathrm{A} 1$ を塞ぎ, 外壁下端ジョイント隙間（浸水口 A2）からの浸水状況を調べる試験で, テスト 1 と同様, サッシ 下枠より下のレベルまで屋外浸水空間に注水する。浸水口 A1 は，外壁パネルを支持する下枠（リップ溝形鋼）と基礎梁の隙 間に発泡ポリエチレン材をはめ込み, 屋外側から防水テープで 覆うことによって閉塞される。これにより，壁体内通気口も閉 鎖される。

テスト 3 : 浸水口 $\mathrm{A} 1, \mathrm{~A} 2$, 及びサッシ枠内を塞ぎ, サッシ枠外隙 間（浸水口 B）からの浸水状況を調べる試験で, サッシ下枠を 越えるレベルまで屋外浸水空間に注水する。このとき, 浸水口 A1 と A2 を完全に密閉するために, 外壁下部から基䃈上部まで をビニルシートで覆い, その周囲を防水テープとシリコン剂で 止水する。また, サッシ枠内（浸水口 C）からの浸水を完全に 抑えるために，サッシ枠の全面に外側からコンクリート型枠用
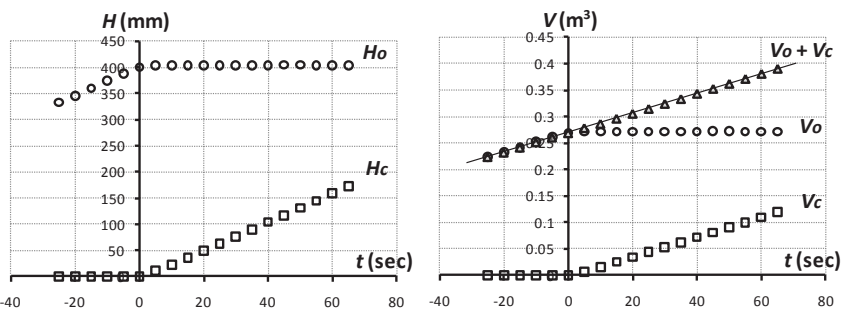

Fig.5 Results of inundation test 1 (inlet A1)
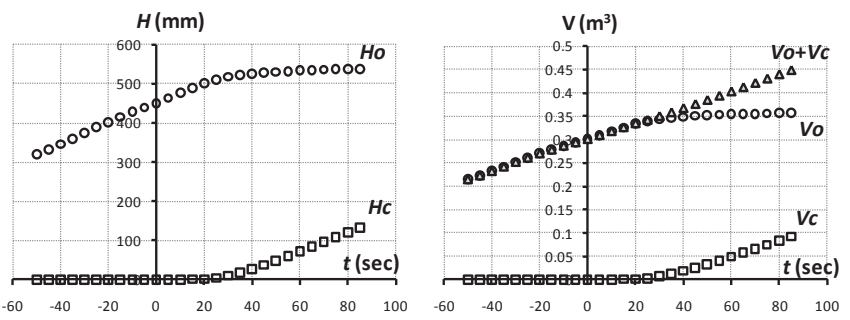

Fig.6 Results of inundation test 2 (inlet A2) 

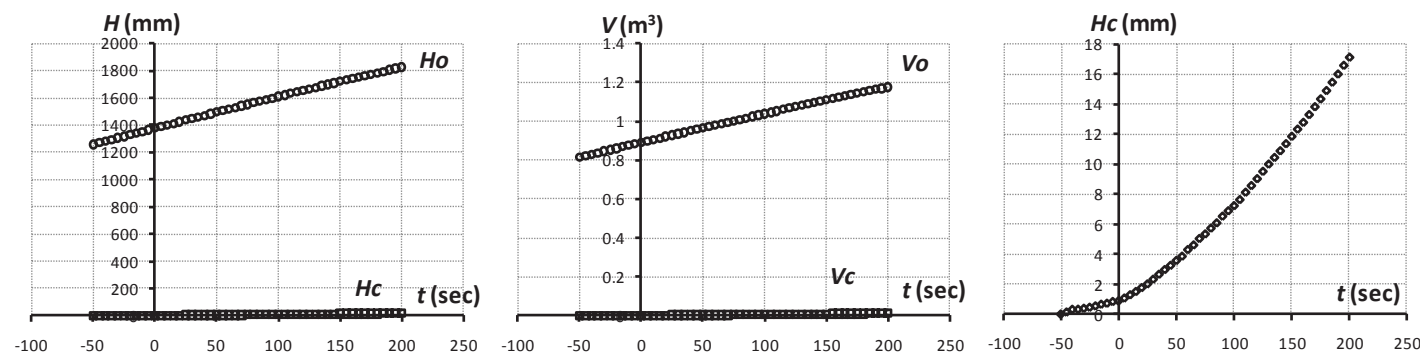

Fig.7 Results of inundation test 3 (inlet B)

合板を防水テープで貼り付ける。

テスト 4 : 浸水口 $\mathrm{A} 1, \mathrm{~A} 2$, 及びサッシ枠外隙間を塞ぎ, サッシ枠 内隙間（浸水口 C）からの浸水状況を調べる試験で, テスト 3 と同様，サッシ下枠を越えるレベルまで屋外浸水空間に注水す る。浸水口 A1, A2 の密閉方法はテスト 3 と同じで, サッシ枠 外隙間（浸水口 B）は，その全周を外面から防水テープで止水 する。

テスト 5 : 連続した基礎上換気口 $\mathrm{A} 1$ を浸水口 $\mathrm{D}$ の部分だけ除い て発泡ポリエチレンと防水テープで塞ぎ，浸水口 $\mathrm{A} 2$ を防水テ ープで完全に密閉したあと, 空サッシ下枠より下のレベルまで 屋外浸水空間に注水する。

\section{5 浸水試験の結果}

\subsection{1 テスト 1 の結果}

テスト 1 （浸水口 A1 を対象）では, 屋外浸水空間に注水した水が 基礎上換気口 $\mathrm{A} 1$ から屋内側に勢いよく流れ出し，ポンプの能力の 関係で基䃈上換気口を越えるレベルまで屋外浸水空間を浸水させる ことができなかった。結果的に, A1 の直上にある浸水口 A2 には水 が浸入しなかった。

屋外浸水深 $H_{o}$ と集水槽の水深 $H_{c}$ の時刻歴, 及びそれを水の貯留体 積 $V_{o}, V_{c}$ に換算した時刻歴を Fig.5 の左と右に示す。横軸の時刻は屋 内浸水が開始した時点を基準にとるのがよいが，流入量が少ないと きはその判定が難しいので, 集水槽に溜まる水の流量が $2.0 \times$ $10^{-5} \mathrm{~m}^{3} / \mathrm{s}$ を超えたときを $t=0$ として全試験結果を統一表示した。 3 回の試験結果は再現性がよく, プロットがほとんど重なるので, 1 回分だけを図示してある。右図で屋外浸水空間と集水槽の水の貯留 体積を合わせたものは時間軸に対して直線となっており，その勾配 はポンプの吐出能力 $\left(0.11 \mathrm{~m}^{3} / \mathrm{min}\right)$ と一致している。

テスト 1 では, 基礎梁が水理学における一種の堰（せき）となり, 屋外浸水空間に注水された水が基礎上換気口（隙間 $16 \mathrm{~mm}$ ）から寸 べて流れ落ちた。基礎上換気口の上端まで浸水させるには, 寸なわ ち越流水深 $16 \mathrm{~mm}$ となるには, 堰の流量計算式 12 によると, $0.50 \mathrm{~m}^{3} / \mathrm{min}$ の給水能力が必要であり, 今回使用したポンプはその 能力に達していない。すなわち, テスト 1 では浸水口 $\mathrm{A} 1$ の直上に ある浸水口 $\mathrm{A} 2$ に水位が届かず，A1のみから屋内側が浸水したこと になる。

\subsection{2 テスト 2 の結果}

テスト 2 （浸水口 A2 を対象）では, 屋外浸水空間に注水した水が 基礎上換気口の直上にある外壁内部に浸入し, それが屋内側に浸水 をもたらした。Fig.4(2)に示すように，外壁サイディングと下地鉄
骨との隙間から水が屋内側に涌き出ている。今回の試験では断熱材 や内壁，床材を取り外しているが，実際の被害状況としては，この 流入した水は床下に流れ落ちるとともに，断熱材が吸水し，内壁の 污損や床上に漏水をもたらすと考えられる。なお，外壁サイディン グ材自身とその目地からの漏水は観察されなかった。

屋外浸水深 $H_{o}$ と集水槽の水深 $H_{c}$ の時刻歴, 及びそれを水の貯留体 積 $V_{o}, V_{c}$ に換算した時刻歴を Fig.6 に示す。浸水口の面積を $a$, 試験 床からの高さを $h$, 浸水口から浸入する水の流速を $v$, その流量を $Q$ と すると, 質量保存則から $Q=a v$, トリチェリの定理から $v=$ $\sqrt{2 g\left(H_{o}-h\right)}$ である $(g$ : 重力加速度)。流量は集水槽に溜まる水の 体積の時間変化であるので $\left(Q=\Delta V_{c} / \Delta t\right)$, 次の関係式が導かれる。

$$
\Delta V_{c} / \Delta t=a \sqrt{2 g\left(H_{o}-h\right)}
$$

Fig.6 に示したデータのうち屋内一の浸水がほぼ定常状態に達し ていると見られる $t \geq 30 \mathrm{sec} の$ 範囲に上式をあてはめて, 重回帰分析 によって $a$ と 欄に示す値となり, 3 回を平均すると，

$$
\begin{aligned}
& \text { 浸水口 } \mathrm{A} 2 \text { の面積 }: a=12.6 \mathrm{~cm}^{2} \\
& \text { 浸水口 A2 のレベル : } h=450 \mathrm{~mm}
\end{aligned}
$$

が得られる。浸水口 A2 のレベル（試験床からの高さ） $450 \mathrm{~mm}$ は, 基礎天端レベル $400 \mathrm{~mm}$ より少し上にあることを意味しており，試 験体の実態に合っている。

浸水口 A2 は外壁の全幅 $2 \mathrm{~m}$ に一様に分布していると考えられる ので, 得られた開口面積 $12.6 \mathrm{~cm}^{2}$ から隙間の幅が $0.63 \mathrm{~mm}$ である ことが分かる。ただし，これは必ずしも実態として存在している開 口ではなく, 浸水がトリチェリの定理に従うとしたときの計算上の 開口面積であることに注意する必要がある。隙間のような開口はそ の寸法を実測することは難儀であるが，浸水に関わる有効開口面積 を浸水試験から推定することが可能である。

\subsection{3 テスト 3 の結果}

テスト 3 （浸水口 B を対象）では, 屋外浸水空間を約 $1,850 \mathrm{~mm}$ まで浸水させた。これは空の高さの約半分の位置である。

屋外浸水深 $H_{o}$ と集水槽の水深 $H_{c}$ の時刻歴, 及びそれを水の貯留体 積 $V_{o} ， V_{c}$ に換算した時刻歴を Fig.7 に示寸。屋内一の流入量が非常に 少ないので, 屋外浸水深はほぼ直線的に増加している。同図右に集 水槽の水位のみを拡大して示してある。

空サッシ枠と壁材は, 雨仕舞いのため, 上枠と壁材の隙間は屋外 側からシリコンコーキングされ，縦枠と壁材の隙間は縦目地で屋外 側からシールされているが，下枠と壁材の隙間はそのままである。 したがって，屋外が浸水したとき，下枠と壁材の隙間から浸入した 


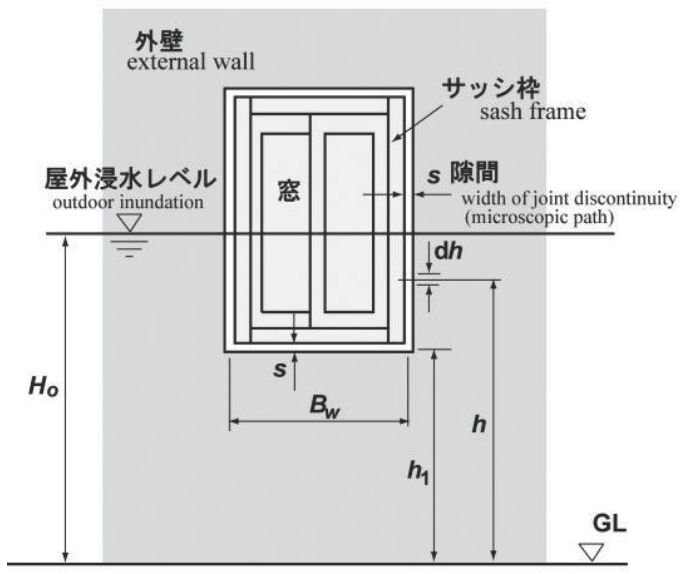

Fig.8 Model of inlet B
Table 1 Calculated areas and heights of floodwater inlets

\begin{tabular}{|c|c|c|c|c|c|}
\hline \multirow{3}{*}{ 浸水口 } & \multirow{3}{*}{ 回数 } & \multicolumn{2}{|c|}{ 浸水口の断面サイズ } & \multirow{2}{*}{$\begin{array}{c}\text { 浸水口の } \\
\text { 高さ位置 } \\
\end{array}$} & \multirow{3}{*}{ 備考 } \\
\hline & & 開口面積 & 開口(隙間)の幅 & & \\
\hline & & $a\left(\mathrm{~cm}^{2}\right)$ & $s(\mathrm{~mm})$ & $h(\mathrm{~mm})$ & \\
\hline \multirow{4}{*}{ A2 } & 1 & 12.5 & 0.63 & 453 & \multirow{4}{*}{$\begin{array}{l}t \geqq 30 \mathrm{sec} \\
s \text { は } a \text { を壁の幅 } 2 \mathrm{~m} \text { で除 } \\
\text { したもの。 }\end{array}$} \\
\hline & 2 & 12.6 & 0.63 & 451 & \\
\hline & 3 & 12.6 & 0.63 & 446 & \\
\hline & 平均 & 12.6 & 0.63 & 450 & \\
\hline \multirow{4}{*}{ B } & 1 & - & 0.0146 & 1,260 & \multirow{4}{*}{$\begin{array}{l}t \geqq 50 \mathrm{sec} \\
\text { サッシトレベル } h_{1} \text { を } \\
1,260 \mathrm{~mm} \text { に固定して回 } \\
\text { 帰分析。 }\end{array}$} \\
\hline & 2 & - & 0.0128 & 1,260 & \\
\hline & 3 & - & 0.0127 & 1,260 & \\
\hline & 平均 & - & 0.0134 & 1,260 & \\
\hline \multirow{4}{*}{$\mathrm{C}$} & 1 & 1.28 & - & 1,220 & \multirow{4}{*}{$\begin{array}{l}t \geqq 30 \mathrm{sec} \\
\text { サッシ下枠の結露排出 } \\
\text { 口, 下かまち隙間から } \\
\text { 浸水。 }\end{array}$} \\
\hline & 2 & 1.27 & - & 1,250 & \\
\hline & 3 & 1.32 & - & 1,230 & \\
\hline & 平均 & 1.29 & - & 1,230 & \\
\hline \multirow{4}{*}{ D } & 1 & 1.31 & - & 409 & \multirow{4}{*}{$\begin{array}{l}t \geqq 50 \mathrm{sec} \\
\text { 基礎上の指定開口 } 16 \\
\times 10 \mathrm{~mm} \text { 况浸水。 }\end{array}$} \\
\hline & 2 & 1.34 & - & 423 & \\
\hline & 3 & 1.40 & - & 442 & \\
\hline & 平均 & 1.35 & - & 425 & \\
\hline
\end{tabular}
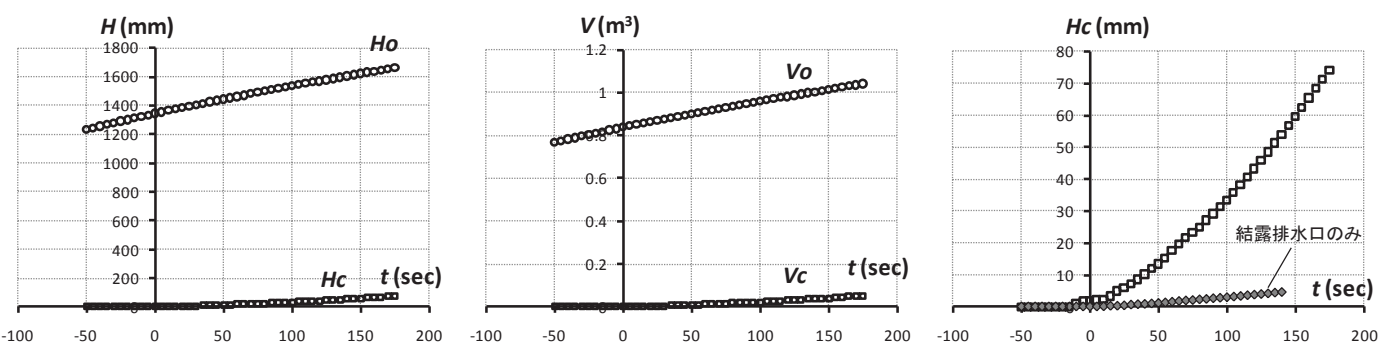

Fig.9 Results of inundation test 4 (inlet C)

水は縦枠と壁材の隙間に回り込むことができる。よって, このテス 卜 3 における浸水口 B は, サッシ下枠と壁材の隙間, 及びサッシ縦 枠と壁材の隙間の両方を考える必要がある。前者は水平で試験床か らの高さが一定であるが, 後者は鉛直で高さが一定でない。そこで, 隙間の幅がサッシ枠の外側に沿って一様と仮定して $s$ と置き, Fig.8 （空を正面から見た図）のように記号を設定する。サッシ縦枠の高 さhの位置にある微小区間 $\mathrm{d} h$ 開口からの流入速度はトリチェリの 定理からv $=\sqrt{2 g\left(H_{o}-h\right)}$, 流量は $\mathrm{d} Q=2 s \cdot \mathrm{d} h \cdot v$ あるので, これ を積分することによって, サッシ縦枠と壁材との隙間からの流量が 次のように求められる。

$$
Q_{v}=\int_{h_{1}}^{H_{o}} d Q=\frac{4}{3} \sqrt{2 g} \cdot s \cdot\left(H_{o}-h_{1}\right)^{3 / 2}
$$

ここで, $h_{1}$ はサッシ下枠のレベル (屋外浸水底面から測った高さ) である。サッシ下枠と壁材との隙間からの流量 $Q_{h}$ については開ロレ ベルが一定であるので, 前記(3)式の開口面積 $a$ を $s \cdot B_{w}$ に置き換えれ ばよい $\left(B_{w}=959 \mathrm{~mm}\right.$ : サッシ下枠の横幅 $)$ よって, サッシ下枠と 縦枠の外周からの浸水流量は次式で表される。

$$
Q_{h}+Q_{v}=\Delta V_{c} / \Delta t=\sqrt{2 g} \cdot s \cdot\left[B_{w}\left(H_{o}-h_{1}\right)^{1 / 2}+\frac{4}{3}\left(H_{o}-h_{1}\right)^{3 / 2}\right]
$$

Fig. 7 に示したデータに重回帰分析を施して上式中の未知数 $h_{1}$ と を求めることは原理的には可能であるが， $V_{c}$ の変化率が非常に小さ いので誤差が大きくなる。そこで, サッシ下枠のレベルは明確であ るので, $h_{1}=1,260 \mathrm{~mm}$ として回帰解析を行った。このとき, Fig.7 右図から屋内への流入量がほぼ安定して計測されていると見られる $t \geq 50 \sec$ の゙ーータを用いた。得られたsの值を $1,2,3$ 回目それぞ れについて Table 1 の浸水口 B の欄に示す。值のばらつきは小さく,

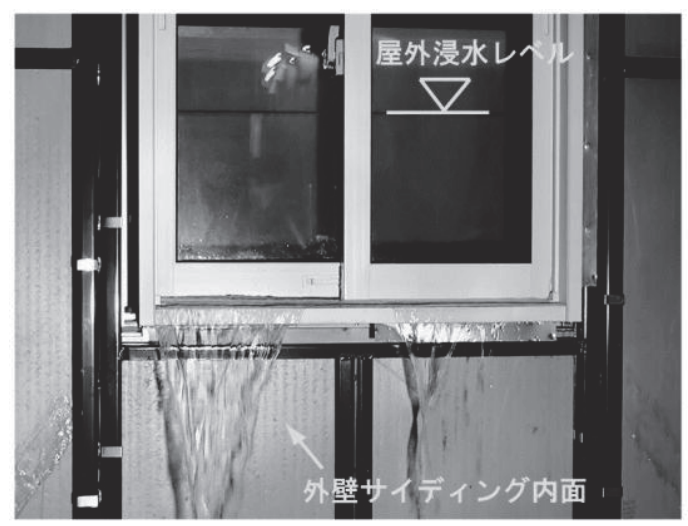

Fig.10 Inundation flow through inlet C

3 回を平均すると次のようになる。

浸水口 B $の$ 隙間幅 : $s=0.013 \mathrm{~mm}$

浸水口 B のサッシ下レベル : $h_{1}=1,260 \mathrm{~mm}$

このことから，空サッシ枠と壁との浸水に関わる隙間は非常に小 さい值であることが分かる。ただし，この隙間が幾何学的に実在す るというわけではなく, トリチェリの定理に従う浸水口の幅をもつ た隙間という意味である。上の計算では, サッシ縦枠と壁材の隙間 に回り込む水によってその部分のみサッシ下枠レベルでの圧力が 0 でないことを厳密に考慮したものであるが，その影響は小さい。サ ッシ下枠と壁材との隙間のみを浸水口として計算しても隙間幅はほ とんど変わらない。 

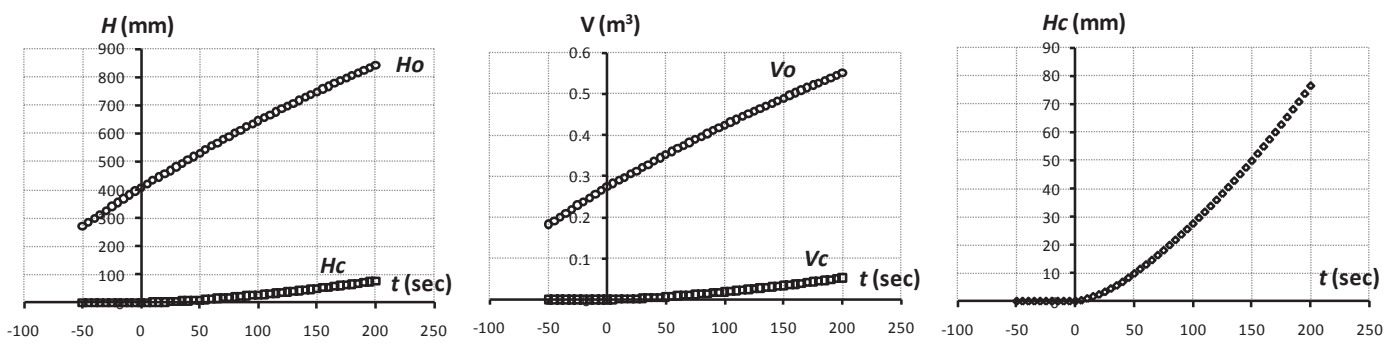

Fig.11 Results of inundation test 5 (inlet D)

\subsection{4 テスト 4 の結果}

テスト 4（浸水口 C を対象）では，屋外浸水空間を約 $1,650 \mathrm{~mm}$ まで浸水させた。これは空サッシの下枠から上に約 $40 \mathrm{~cm}$ の位置で ある。

屋外浸水深および貯留体積の時刻歴を Fig.9 に示す。今回の実験 で, サッシ枠内の隙間からの浸水状沉を観察すると (Fig.10 参照), ほとんどが戸の底部からで, 縦方向の戸当たり部, あるいは引違い 戸の召合せ部分からの浸水は観察されなかった。そこで, 開口が同 一レベルにあるときの(3)式を使って開口面積とレベルを回帰解析 により推定した。その結果を Table 1 の浸水口C の欄に示す。 3 回 の実験におけるこれらの值はほとんど同じで，平均すると，

$$
\begin{aligned}
& \text { 浸水口 Cの面積 }: a=1.29 \mathrm{~cm}^{2} \\
& \text { 浸水口 C のレベル : } h=1,230 \mathrm{~mm}
\end{aligned}
$$

となる。

浸水口のレベルがサッシ下枠より $40 \mathrm{~mm}$ ほど低い位置に推定さ れているが，これは誤差と思われる。誤差要因としては，浸水箇所 から集水槽まで距離があるため, 屋外浸水深と浸水流量の測定值に タイムラグが発生することによると考えられる。そのような場合に は，aを過大推定しかつhを過小推定することはないが，それ以外は いずれも起こりうる。したがって, 上記の $a$ の值は若干過小推定に なっている可能性がある。ただし，これは屋外水位が上昇する条件 で測定した場合であって，下降する場合には逆になる。

本研究で用いた空サッシの下枠には, 空の結露水を屋外に排出す るためのスリット孔（下枠上面）と外開きの弁を内包する開口（下 枠側面の屋外側）が設けられており，ここは浸水口となりうる (Fig.4(4)参照)。そこで, この屋外側の結露排水口 $(8 \times 50 \mathrm{~mm} \times 2$ か所）だけを露出させ，それ以外のサッシ枠内隙間を完全に塞いで 浸水試験を行ったときの結果を Fig.9 右図に追記した。これを見る と, 結露排水口からの浸水はサッシ枠内隙間全体の $9 \%$ に過ぎない。 すなわち, サッシ枠内隙間からの浸水はもっぱら, 戸車の付いた下 框とサッシレールとの隙間からであることが分かる。仮に，(8a)式 の浸水口面積の $91 \%$ がこの隙間からとし, それをサッシ枠の内法 $829 \mathrm{~mm}$ で割ると隙間の平均幅は $0.14 \mathrm{~mm}$ と推定される。

\section{5 .5 テスト 5 の結果}

テスト 5 (浸水口 D を対象）では, 屋外浸水空間を約 $850 \mathrm{~mm}$ ま で浸水させた。これは基礎天端から約 $45 \mathrm{~cm}$ の位置である。

屋外浸水深および貯留体積の時刻歴を Fig.11 に示す。前記(3)式 を使って開口の面積と高さ位置を回帰解析により推定した結果を Table 1 の浸水口 D の欄に示す。 3 回の実験におけるこれらの值は ほとんど同じで，平均すると，

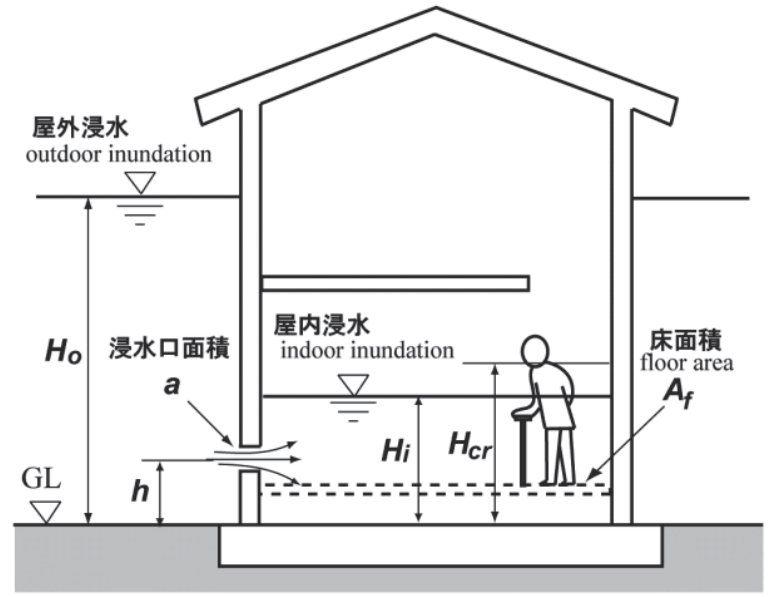

Fig.12 Indoor inundation of house exposed to flood

$$
\begin{aligned}
& \text { 浸水口 D の面積 } \quad: a=1.35 \mathrm{~cm}^{2} \\
& \text { 浸水口 D のレベル }: h=425 \mathrm{~mm}
\end{aligned}
$$

となる。浸水口のレベルは実際に設置した基礎上の位置とほぼ一致 している。浸水口の推定面積の実開口面積 $1.60 \mathrm{~cm}^{2}$ に対する比，す なわち流量係数は 0.84 となる。オリフィスの流量係数はその形態に 依存して変化するが，この浸水口のように長方形断面の見付け幅に 対して開口の奥行きが同程度以上の場合には 0.86 程度とされてお り 13), 今回の実験結果とも符合している。

テスト 5 の結果は，この浸水試験方法が浸水口の面積と高さ位置 を的確に推定できることを支持している。次章で述べるように，家 屋の浸水について, 浸水口の面積とレベルが決定的であるので, こ の浸水試験方法が有用な試験方法であることが確認できたと言える。

\section{4. 浸水試験データの利用に関する考察}

今回の試験で注目したのは，家屋の外壁面に潜在する浸水口の面 積である。建物の屋外が洪水等によって浸水したとき，建物の外壁 面の開口から水が浸入して屋内が浸水する。これを模式的に描くと Fig.12のようになる。地盤面から測った屋外の浸水深を $H_{o}$, 屋内の 浸水深を $H_{i}$, 浸水口の高さを $h$, その面積を $a$, 建物 1 階の床面積を

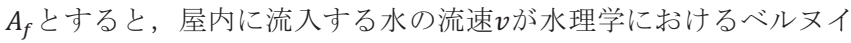
の定理（開放空間への流出の場合はベルヌイの定理の特別な場合と してトリチェリの定理）12)から簡単に計算でき，それを基にして， 屋内に浸入する水の流量 $Q=a v$, 屋内浸水深 $H_{i}$ が次のように計算で きる。式中の $g$ は重力加速度, $t$ は時間である。ここでは一つの浸水 口のみを対象とし，また，簡単のため，屋外浸水深は定常状態にあ 
るものとする。

$H_{i} \leq h$ とき,

$$
\begin{array}{r}
v=\sqrt{2 g\left(H_{o}-h\right)}, \text { 及び } A_{f} \frac{\mathrm{d} H_{i}}{\mathrm{~d} t}=Q=a v \text { より }, \\
\frac{\mathrm{d} H_{i}}{\mathrm{~d} t}=\frac{a}{A_{f}} \sqrt{2 g\left(H_{o}-h\right)}
\end{array}
$$

となるので, これを $t=0$ のとき $H_{i}=0$ の初期条件で解くと，

$$
H_{i}=\frac{a}{A_{f}} \sqrt{2 g\left(H_{o}-h\right)} \cdot t
$$

となる。よって, $H_{i}=h$ となるときの時刻 $t_{1}$ は次式で表される。

$$
t_{1}=\frac{A_{f}}{a} \cdot \frac{h}{\sqrt{2 g\left(H_{o}-h\right)}}
$$

次に, $h<H_{i} \leq H_{o}$ のとき, 水位差が $H_{o}-H_{i}$ であるので,

$$
\frac{\mathrm{d} H_{i}}{\mathrm{~d} t}=\frac{a}{A_{f}} \sqrt{2 g\left(H_{o}-H_{i}\right)}
$$

となる。この $H_{i}$ に関する微分方程式を $t=t_{1}$ のとき $H_{i}=h$ の条件で解 くと次式が得られる。

$$
H_{i}=H_{o}-\left(\frac{2 H_{o}-h}{2 \sqrt{H_{o}-h}}-\frac{a}{A_{f}} \sqrt{\frac{g}{2}} \cdot t\right)^{2}
$$

以上より, 屋内がある危険浸水深 $H_{c r}$ に達するまでの所要時間 $t_{c r}$ は次式で表される。危険浸水深は, 人命保全のほか, 電気設備, 危 険物, 重要物の浸水防止など様々な観点から設定される。

$$
\begin{aligned}
& H_{c r} \leq h \text { のとき, } t_{c r}=\frac{A_{f}}{a} \cdot \frac{H_{c r}}{\sqrt{2 g\left(H_{o}-h\right)}} \\
& h<H_{c r} \leq H_{o} \text { のとき, } t_{c r}=\frac{A_{f}}{a} \sqrt{\frac{2}{g}} \cdot\left(\frac{2 H_{o}-h}{2 \sqrt{H_{o}-h}}-\sqrt{H_{o}-H_{c r}}\right)
\end{aligned}
$$

上式から分かるように, 浸水が始まってから屋内が危険浸水深に 達するまでの時間は, 浸水口の面積 $、$ に反比例する。すなわち, 開 口が大きいほど, 居住者が逃げ遅れたり重要物の退避が間に合わな いというリスクが高まる。このことから, 浸水口の面積が, その高 さ位置とともに, 水害に対する設計で重要な変数であることが分か る。なお, 浸水口が高さ方向に複数存在するときの複合浸水では, 水理学上, 上記の演算を浸水口のレベルごとに段階的に行えばよい と考えられるが,このことは今回の実験では確認できていないので, 複合浸水についてはさらに検討が必要である。

計算例を浸水口 A2 (外壁下端ジョイント隙間) について示すと次 のようになる。建物の平面寸法が $10 \mathrm{~m} \times 12 \mathrm{~m}$, 屋外浸水深が $3 \mathrm{~m}$ の 場合, 屋内浸水深が $2 \mathrm{~m}$ に達するに要する時間は(13)式から 24 分と なる。洪水による浸水継続時間が半日とすると, それまで屋内浸水 深が $2 \mathrm{~m}$ に達しないようにするには, A2 の隙間を現状の 1/30 にし なければならない。

現在の水害八ザードマップにはエリアごとの想定浸水深が示され ているが, 将来的には浸水継続時間の情報も提供されることが期待 されている 14)。そうなると, 屋内が危険浸水深に達するまでの所要 時間のほうが浸水継続時間より長くなるように設計しておけば，安
全性の確保はもちろん, 経済的損失を減じることができるようにな る。現時点では，建築設計において浸水リスクが考慮されていない が，浸水対策は設計当初から考えておく必要があると著者らは考え ている。

\section{5. 結び}

陸上を汇濫する洪水や津波に暴露された家屋の浸水状況を再現す る試験装置を考案し, 空の付いた鉄骨系プレハブ住宅外壁の浸水試 験を行った。浸水試験装置は屋外側を深さ $3 \mathrm{~m}$ まで浸水させること ができる。屋外浸水深と屋内への流入量を時間軸上で連続的に測定 することによって, 浸水経路となる浸水口の面積と高さ位置を推定 することができた。

今回の実施例では, 床下換気の役割をする基䃈上換気口がもっと も大きな浸水経路となること, また, 空サッシ下枠と戸車の付いた 下框の隙間や外壁下端における壁材と鉄骨下地とのジョイントも無 視できない浸水口であり, さらに, 微小ではあるが, 空サッシ下枠 の結露排水口や空サッシ枠と壁材の隙間も潜在的な浸水口となって いることが分かった。これら浸水口の面積と高さ位置が分かれば, 屋内が危険水位に達するまでの時間を水理学におけるべルヌイの定 理を使って推定できることを示した。

\section{参考文献}

1）国土交通省 水管理 - 国土保全局 河川計画課：平成 22 年版水害統計, 2014.2 .

2）国土交通省 : 水害対策を考える，2007.

3）国土交通省・防災関連学会合同調查団：米国ハリケーン・サンディに関寸 る現地調查報告書（第二版）一先進国の大都市を初めて襲ったニューヨー ク都市圈大水害からの教訓一, 2013.7 .

4）国土交通省: 超巨大台風がおこす高潮による首都圈大規模水害からみなさ んを守るために（高潮パンフレット），2013.10.

5）国土交通省: 未曾有の大雨がおこす洪水による首都圈大規模水害からみな さんを守るために（洪水パンフレット），2013.10.

6）日本建築防災協会: わが家の大雨対策一安心な暮らしのために一, 2001.7.

7) 吉野文雄, 本間久枝: 総合治水対策としての建築物の耐水化の技術的検討, 土木技術資料，Vol.23， No.7， pp.343-348， 1981.7.

8）上澤道彦ほか: 鋼製建具での耐水圧及び水密性能の検証手法, 日本建築学 会大会学術講演梗概集, 材料施工, pp.1451-1456, 2013.8 .

9）井上修作, 水島靖典, 佐藤吉之: 建物内部に浸水する津波計算に関する研 究, 日本建築学会大会学術講演梗概集, 都市計画, pp.671-672, 2013.8.

10) American Society of Civil Engineers: Flood Resistant Design and Construction, ASCE Standard ASCE/SEI 24-05, 2006.

11）亀井 勇: 浸水速度, 流水高と被害の関倸（建築物の水害特性に関する研 究）, 日本建築学会関東支部第 25 回研究発表会, pp.1-4, 1959.1 .

12) 本間 仁, 米元卓介, 米屋秀三: 水理学入門 (改訂版), 森北出版, 1979.4.

13) Franzini, J.B and Finnemore, E.J.: Fluid Mechanics with Engineering Applications, 9 9 $^{\text {th }}$ Edition, WCB/McGraw-Hill, pp.524-534, 1997. 14）中央防災会議: 大規模水害対策に関する専門調查会報告, 2010.4. 


\title{
INUNDATION TEST METHOD FOR FLOODED HOUSES WITH APPLICATION
}

\author{
Hitoshi KUWAMURA*, Tsuyoshi KOYAMA**, Hiroki OKUNO *** \\ and Yoshiharu SATO*** \\ * Prof., Dept. of Architecture, School of Engineering, The University of Tokyo, Ph.D. \\ ** Assist. Prof., Dept. of Architecture, School of Engineering, The University of Tokyo, Ph.D. \\ *** Grad. Stud., Dept. of Architecture, School of Engineering, The University of Tokyo, B. Eng.
}

Houses on land in many places in the world are exposed to inundation due to flood, tsunami, and flood-tide. This research project is planned for hydro-hazard mitigation with a focus on inundation resistance of flooded houses. This first paper introduces a testing method for quantifying flood resistance of houses and its application to an actual-scale housing wall with a window.

The testing apparatus, as outlined in Fig.1, is composed of a main frame, a water reservoir, a collector, and piping. The main frame supports a back panel and a specimen wall. The frame is accompanied by a bottom plate and side plates which are continuously welded to each other for preventing the leakage of water. The back panel is detachable so that the construction work is facilitated during the erection of the specimen in the main frame. The space surrounded by the back panel, bottom plate, side plates, and wall specimen forms the outdoor inundation space of 3-meter depth. The outer inundation space is filled with water by a water pump from the reservoir. The inundation flows from outside to inside are entirely gathered into the collector. The depths of the water in the outer inundation space and the collector are continuously measured by capacitance-type level gauges as shown in Fig.2.

The test specimen is part of an external wall of ordinary prefabricated steel houses as shown in Fig.3. The light-gauge steel frame of the specimen wall is supported at the bottom by a foundation of rectangular hollow section steel and is connected at the top to the testing frame. The test specimen accommodates sliding windows set in an aluminum sash frame. The material of the external wall is a water proof fiber reinforced cement siding board.

The inundation flows from outside to inside are through an opening for under-floor ventilation symbolized by inlet A1, joint discontinuities at the bottom of wall by A2, a gap between sash bar and wall panel by B, and a gap between sash bar and window rail by $\mathrm{C}$, which are indicated in Fig.3 and Fig.4. Inundation tests 1 to 4 are performed step by step to quantify the dimensions and heights of these inlets, after that test 5 is conducted for a size-specified opening symbolized by D which is set on the foundation to calibrate the testing method.

The results of inundation tests are shown in Fig.5 to Fig.11 with commentary illustrations of Fig. 8 and Fig.10. The graphs in the figures show the elevations of water levels of the outer inundation space and the inside collector with elapsing time and also the water volumes therein. According to Torricelli's theorem, the areas and heights of these inlets are calculated by means of regression analysis, the results of which are given in Table 1. The opening A1 is large enough to release the supplied water entirely into the collector, which suggests that the foundation opening for ventilation is serious for indoor inundation of houses. Other openings or joint discontinuities are found relatively small, but still potential for indoor inundation. The result of test 5 for inlet $\mathrm{D}$ demonstrated that the calculated dimension and height both match to the actual ones well.

The data obtained from the inundation test will enable engineers to calculate the rate of inflow and the time allowances up to critical rise of indoor inundation as given by Eqns. 12 and 13 with Fig.12, which is substantially important for evacuation of residents and valuables. 